\title{
FOXO6 Gene
}

National Cancer Institute

\section{Source}

National Cancer Institute. FOXO6 Gene. NCI Thesaurus. Code C101410.

This gene may play a role in transcriptional activation. 